\title{
REPUBLICAN FORM OF GOVERNMENT: FEATURES OF ITS MIXED FORM IN UKRAINE
}

\section{Vladislav Oliinyk ${ }^{1}$}

DOI: https://doi.org/10.30525/978-9934-588-84-6-13

The republic is a dominant state government in the world. About 160 out of 200 present-day states proceeded to a democratic republican government. A main feature of the republic, which differs it from the monarchy, is that the highest bodies of the public state power are elected by people for a definite term. They are subordinate to people, perform their functions according to the Constitution and other laws, and in case of illegal activity they are responsible for various kinds of legal, political and moral actions.

There are some legal features of the republic: a) limiting the power of the highest bodies of the state government for a term defined in the Constitution laws; b) electivity and periodic change of the highest body of the legislative power and head of the state(President); c) responsibility of head of the state; d) supremacy of the acts adopted by the highest representative legislative body of the country.

Collegiate body of the representative power (parliament), collegiate body of the executive power (government) and the system of the highest judicial bodies are supposed to be in the parliamentary government. The state and power functions are distributed equally between them. The government can perform its functions successfully only if it is trusted by the government being responsible to it. One of the brightest features of this form of government is the political responsibility.

The Constitution of Ukraine adopted on June, 28, 1996, fixed a model of the mixed republic. The Constitution of Ukraine defines the President as head of the state. This gives the reasons to speak about him as an embodiment of the state and state power but not as its branch [1].

In accordance with Article 113 of the Constitution Cabinet of Ministers is the highest executive body of power. The procedure of its formation corresponds to the so-called extra-parliamentary model of the government when the President, not the parliament, is given a leading role [1]. Hot discussions as to the structure of the Ukrainian government led to

\footnotetext{
${ }^{1}$ Academy the State Penitentiary Service, Ukraine
} 
establishing unicameral Verkhovna Rada according to the new Constitution of Ukraine.

Opponents of the modern Ukrainian parliamentary and presidential government note that in Ukraine there are two verticals of power, presidential and parliamentary, which often have the same functions, that leads to opposing. Besides, political and social tension increases a lot on the eve of the presidential elections in the country. Advocates of the parliamentary government in Ukraine believe that expenses of financial, economic and political resources on keeping the presidential power and on electoral presidential company will decrease when the country proceeds to this model, and, as a result of this one of the factors of the coming social and political opposing will be eliminated. Only elections to the parliament will have priority in the country and after them the parliamentary majority, forming the government, will define the further way in the development of the country. A. Petryshyn and S. Serohina believe that such model suggests a high level of political and legal perception, stable «political memory» of the society that make impossible to manipulate public opinion by the leaders of political parties. This model provides the role of head of the state not as a manager but, first of all, as a symbol of the strict observance of the Constitution requirements by all political players. Finally, the parliamentary republic is guided by the politically structured representative body that functions in the conditions of complete transparency with legible, formalized, legal procedures [2, p. 58].

At first sight, this system is ideal for the state. But, it is known that there is no panacea for all diseases in the world. So, the parliamentary government as well as all the rest have a number of drawbacks. The drawbacks of the parliamentary system and also of the presidential one are the continuation of its advantages. Unsteadiness of the coalitions in the parliamentary systems leads to the frequent change of the governments, to the unsteadiness of the whole political system (a typical example is Italy and its frequent crisis in the parliament). The government will not have enough pragmatism if it is necessary to follow a certain ideological way. Besides, it is not clear if it is possible to provide the transition from the present to a new form of government. To do this it is necessary to make considerable changes in the Constitution that can lead to a serious and even dangerous political crisis in the state.

Is it worth establishing the parliamentary government in Ukraine? S. K. Bostan thinks that it is worth doing it but in the distant future [3, p. 34]. But today it is necessary to take into account that Ukraine is a transitional 
state which has mixed (segmental) essential and formal features. This suggests setting up the tasks to reform some institutions of the state according to present temporary realities. The earnest of success in the mentioned reforms is the perception of their performance in stages.

One can draw the following conclusions:

- Interrelationship of the parliament, head of the state and the government are the main criteria of defining the republican government;

- Considering these criteria one can define three main kinds of republics: presidential, parliamentary and mixed, which in its turn is divided into presidential and parliamentary, parliamentary and presidential;

- Main features of the presidential republic is legal liability of the government to the President; in the parliamentary republic the government is liable to the parliament and in the mixed republic there is double liability of the government both to the president and the parliament. One of the main features of the parliamentary republic is also election of the president by the parliament or by special parliamentary board. President in the parliamentary republic mainly performs the representative functions and doesn't have real power;

- According to the above-mentioned criteria and features Ukraine is a parliamentary and presidential mixed republic but some elements prove the nonconformity of the Ukrainian model of the state government with the classic model of the parliamentary and presidential republic;

- Parliamentary and republican model of government would be the best for Ukraine. But considering a complicated political and social situation in the state at present time, a rather complex mechanism of making the constitutional changes, unpreparedness of the most part of the ruling elite to change the Constitution in the part related to the form of government in Ukraine.

Taking this into account we recommend:

- To create a long term project (for 5 years) to proceed from the mixed to the parliamentary republic. The project would also include obligatory changes in the Constitution of Ukraine;

- Public mass media should inform about the procedure of reforming government and explain its possible aspects;

- We consider that it is advisable to hold a national referendum on changing the form of government in the state. 


\section{References:}

1. Lysenkov, S. L. (1997). Konstytuciya Ukrayiny: Materialy do vyvchennya [Constitution of Ukraine: materials for study]. Kyiv: Lybid, p. 95.

2. Petryshyn, O., \& Serogina, S. (2009). Zmishana respublikanska forma derzhavnogo pravlinnya: pytannya teoriyi ta praktyky [Mixed republican form of government: questions theory and practice]. Law of Ukraine, no. 10, pp. 57-60.

3. Bostan, S. K. (2017). Forma pravlinnya suchasnoyi derzhavy: problemy istoriyi, teoriyi. praktyky [Form of government of the modern state: problems of history, theory, practice]. Zaporizhya: Law institute, pp. 121-122.

\section{THE QUESTIONS OF ASSESSMENT OF THE COST OF SERVICES AT CARRYING OUT COMMODITY EXAMINATIONS}

\section{Inna Sabadash ${ }^{1}$}

DOI: https://doi.org/10.30525/978-9934-588-84-6-14

Development of new directions in the performance of various types of examinations and expert research is one of the priority areas of scientific activity of specialists of state specialized forensic institutions of the Ministry of Justice of Ukraine. One of the problematic issues that arises at the present stage of development of forensic examination is to determine the cost of services. When conducting commodity research to determine the cost of services, within the expert specialty «Determining the cost of machinery, equipment, raw materials and consumer goods», there is a lot of controversy and doubt both among forensic experts working in state expert institutions and among appraisers. This is due to the fact that the service is a product that is immeasurable and intangible. Also one of the arguments is that the word "service» is not included in the name of the specialty and does not refer to the objects of assessment in intangible form, according to the definitions of the national standard № 1 «General principles of property valuation and property rights», which sets out the definition of Intangible assets - objects of valuation that do not exist in tangible form, but allow to obtain certain economic benefits. Objects in intangible form include financial interests (shares, stocks, shares, options,

\footnotetext{
${ }^{1}$ Kharkiv Research Institute of Forensic Examinations of the Ministry of Justice of Ukraine, Ukraine
} 